\title{
Taxonomy and affinities of African cenozoic metatherians
}

\author{
Taxonomía y afinidades de los metaterios cenozoicos africanos
}

Vicente D. CRESPO (1) \& Francisco J. GOIN (1)

\begin{abstract}
The record of extinct African metatherians (Mammalia, Theria) is scanty, restricted in time (Eocene-Miocene), and its taxonomy is still subject of debate. A review of all African metatherians, or alleged metatherians, known up to now, led us to the recognition of only three taxa referable to this group: (1) Kasserinotherium tunisiense (Peradectoidea?), from the early Eocene of Tunisia; (2) Peratherium africanum (Herpetotheriidae), from the early Oligocene of Egypt and Oman, and (3) an indeterminate Herpetotheriidae? from the early Miocene of Uganda. Herpetotheriids probably reached Afro-Arabia from Europe in one or more dispersal waves since the early Oligocene. Kasserinotherium, on the contrary, suggests an earlier (Paleocene) arrival from South America, judging from its alleged affinities with South American and Australian taxa. Such a migration event (probably, through a filter corridor such as the Rio Grande Rise-Walvis Ridge system in the South Atlantic) may also explain the enigmatic presence of polydolopimorphian metatherians in the Cenozoic of central Anatolia (Turkey). A more radical hypothesis is that all European (Eurasian?) Marsupialiformes have an ultimate origin in South America, from where they dispersed via Africa by the Paleocene-earliest Eocene.

Resumen: El registro de metaterios (Mammalia, Theria) africanos extintos es escaso, temporalmente restringido (Eoceno-Mioceno) y su taxonomía es aún objeto de debate. Una revisión de la totalidad de los metaterios, o supuestos metaterios de este continente nos llevó al reconocimiento de sólo tres taxones referibles a este grupo: (1) Kasserinotherium tunisiense (Peradectoidea?), del Eoceno temprano de Túnez; (2) Peratherium africanum (Herpetotheriidae), del Oligoceno de Egipto y Omán, y (3) un Herpetotheriidae? indeterminado del Mioceno temprano de Uganda. Los herpetotéridos probablemente llegaron a Afro-Arabia en una o más oleadas de dispersión a partir del Oligoceno temprano. Kasserinotherium, por el contrario, sugiere una llegada más temprana (Paleoceno) desde América del Sur, a juzgar por las afinidades sugeridas con formas de este último continente y de Australia. Un evento migratorio de este tipo (ocurrido, probablemente, a través de un corredor de filtro como el sistema Rio Grande-Cadena de Walvis en el Atlántico Sur) podría también explicar la enigmática presencia de metaterios polidolopimorfios en el Cenozoico de Anatolia central (Turquía). Una hipótesis más radical postula que todos los Marsupialiformes europeos (o, incluso, los de Eurasia en su conjunto) tuvieron un origen último en América del Sur, desde donde se dispersaron vía África hacia el PaleocenoEoceno más temprano.
\end{abstract}

Received: 20 January 2021

Accepted: 24 May 2021

Published online: 28 June 2021

\section{Corresponding author:}

Vicente D. Crespo

vidacres@gmail.com

\section{Keywords:}

Mammalia

Metatheria

Africa

Cenozoic

Biogeography

\section{Palabras-clave:}

Mammalia

Metatheria

Africa

Cenozoico

Biogeografía

\section{INTRODUCTION}

Living metatherians are widely distributed both in Australasia and in the Americas. During the last hundred million years, however, they occupied every single continent on Earth, even though their temporal ranges and diversity were strongly unequal. The earliest records of Metatheria come from the Early Cretaceous (Aptian-Albian) of North America, where they had a wide distribution, both temporal and geographical (Crochet, 1980; Gunnell, 2010; Williamson et al., 2014; Goin et al., 2016; Bi et al., 2018). Previously, Sinodelphys was included in Metatheria (Luo et al., 2003), but posterior analyses showed closer affinities with the Eutheria (Bi et al., 2018). The discovery of Juramaia indicates that the dichotomy between Metatheria and Eutheria was a Late Jurassic event, probably prior to $160 \mathrm{Ma}$ (Luo et al., 2011).

The mammalian record from the Paleogene of Africa is very scarce; around 40 localities have been found, mainly concentrated in the Maghreb, although the literature of this period is dominated by the site of Fayum (Pickford et al., 2008). By contrast, the Paleogene record of the African Southern Hemisphere is limited to a very few localities, and only one site in East Africa (Van Couvering \& Delson, 2020). Of all these sites, only

(C) The Author(s) 2021. This is an open-access article distributed under the terms of the Creative Commons Attribution 4.0 International License (for details please see http://creativecommons.org/licenses/by/4.0/), which permits use, copy, adaptation, distribution, and reproduction in any medium or format, as long as you give appropriate credit to the original author(s) and the source. 
three have yielded metatherian remains (excluding Moroto, which is from the Miocene), all of them being very scarce. Because of this, a great subordination of these taxa to eutherians can be observed, probably because the ecological niches of these new immigrants were already occupied by other taxa (see below). Nevertheless, large parts of Africa are still unknown and may reveal new information on the taxonomy, affinities and distribution of African metatherians. The Cenozoic record of metatherians in Europe is relatively abundant and ranges from the early Eocene to the middle Miocene (Crochet, 1980). However, in other Old World continents their record is much scarcer (Crochet et al., 2007; Gunnell, 2010). This is particularly the case for Africa (Fig. 1), whose metatherian record is uneven, quite fragmentary, and controversial. No Mesozoic metatherians are known from Africa (Averianov et al., 2003), leading to the assumption that they arrived there during Cenozoic times either from Europe, or from South America, or both (see below).

The Cenozoic record of metatherian mammals in Africa is still a subject of debate. Remains of African metatherians are scarcely found, are represented by isolated, often fragmentary specimens, and are restricted to its central and northernmost regions. In addition, there is an ongoing debate on the metatherian nature of several of these taxa (Gunnell, 2010).
Up to now, only three African taxa are unambiguously referable to the Metatheria: (1) Peratherium africanum Simons \& Bown, 1984, from the early Oligocene of Egypt and Oman (Arabian Peninsula); (2) Kasserinotherium tunisiense Crochet, 1986, from the early Eocene of Tunisia, and (3) an indeterminate ?herpetotheriid taxon from the early Miocene of Uganda. Other alleged metatherian taxa from Africa have been disputed as probable eutherians or mammals of still unknown affinities: (4) an indeterminate mammal from the Late Cretaceous of Madagascar; (5) Garatherium mahboubii Crochet, 1984 from the early Eocene of Algeria; (6) Ghamidtherium dimaiensis Sánchez-Villagra et al., 2007 from the late Eocene of Egypt; and finally, (7) two upper molars also coming from the late Eocene of Egypt were described as enigmatic mammals of uncertain (and even possibly metatherian) affinities.

Here we provide a review of all African metatherians, or alleged metatherians, known up to now. Because of its geographic vicinity with Africa, we also consider one case of an alleged metatherian from Madagascar. We compare them with eutherian and other metatherian lineages, and discuss their possible affinities. We also argue on the possible dual origin of Cenozoic African metatherians, thus adding to the ongoing discussion on the origins and biogeographical significance of these still enigmatic mammals from the Afro-Arabian record.

A
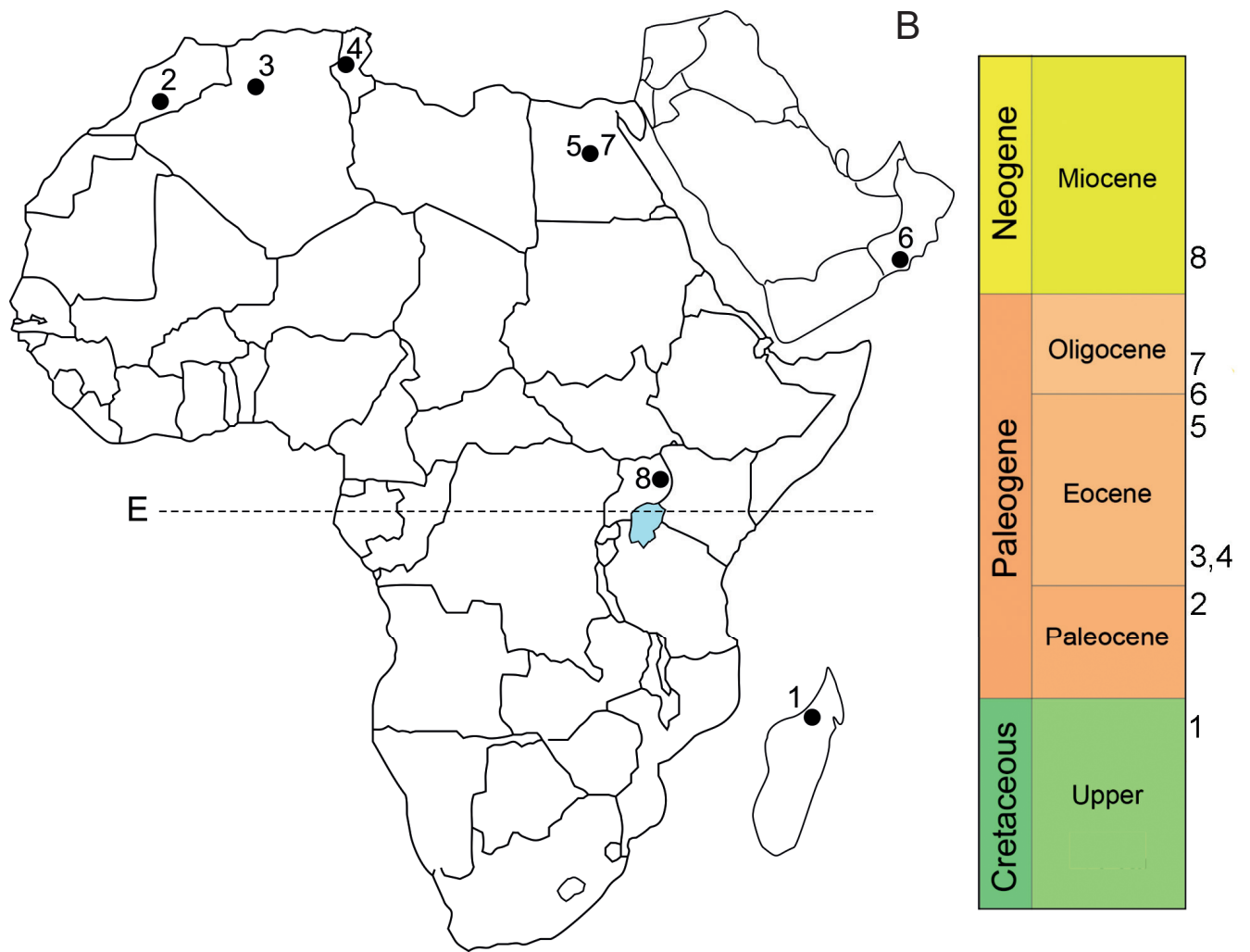

Figure 1. A, Map of Africa and the Arabian Peninsula showing the fossil localities mentioned in this work. Included are localities of both metatherians and previously alleged metatherians; B, Stratigraphic column of the Cenozoic Era indicating the ages of the metatherian taxa, or alleged metatherians, mentioned in this work; E, Equator; 1, Zhelestidae, gen. et sp. indet; 2, ?Garatherium todrae; 3, Garatherium mahboubii; 4, Kasserinotherium tunisiense; 5, Ghamidtherium dimaiensis; 6-7, Peratherium africanum; 8, Herpetotheriidae? gen. et $\mathrm{sp}$. indet. 
Institutional Abbreviations. CGM, Cairo Geological Museum, Cairo, Egypt; DPC, Duke University Primate Center, Durham, United States of America; TQ, Taqah collections, Université Montpellier II, Montpellier, France; UM MOR II, Moroto II locality collections, Uganda Museum, Kampala, Uganda; EY, Cartographic Service, National Mining Bureau, Tunisia; UA, University of Antananarivo, Madagascar.

Anatomical and other abbreviations. Ma, Megannum, one million years in the radioisotopic time scale; $\mathbf{P} / \mathbf{p}$, upper/lower premolars; $\mathbf{M} / \mathbf{m}$, upper/lower molars; terminology of molar structures follows Goin et al. (2016); StA, StB, StC, StD, stylar cusps in the upper molars.

\section{SYSTEMATIC PALAEONTOLOGY}

The material discussed here has been studied from the direct observation of their remains (Kasserinotherium tunisiense and Garatherium mahboubii) housed in I'Institut des Sciences de l'Evolution de Montpellier (Université de Montpellier, France), high quality photographs (Herpetotheriidae? genus and species indet.), and the rest from both their original publications and revisions. In addition, these taxa have been compared with reference collections of metatheria, both originals and casts, of European, South American, North American and Asian origin housed at Museo de La Plata (Universidad Nacional de La Plata, Argentina), I'Institut des Sciences de l'Evolution de Montpellier (Université de Montpellier, France), and Muséum national d'Histoire naturelle (Paris, France). We assume

Table 1. Measurements (in $\mathrm{mm}$ ) of all upper and lower molars of the African metatherians mentioned in this work (from Simons \& Bown, 1984; Crochet, 1986; Crochet et al., 1992; Pickford \& Mein, 2006; Hooker et al., 2008). L, length; W, width; Wtr, width trigonid; Wta, width talonid; Min, minimum; Max, maximum.

\begin{tabular}{|c|c|c|c|c|c|c|}
\hline Element & Collection & Measurement & $\mathbf{n}$ & Min & Mean & Max \\
\hline \multicolumn{7}{|c|}{ Peratherium africanum } \\
\hline \multirow[t]{2}{*}{ dp3 } & $\mathrm{TQ}$ & L & 1 & & 1.75 & \\
\hline & & W & 1 & & 0.95 & \\
\hline \multirow[t]{2}{*}{ p2 } & CGM & L & 1 & & 1.75 & \\
\hline & & W & 1 & & 1.00 & \\
\hline \multirow[t]{2}{*}{ p3 } & CGM & L & 1 & & 1.70 & \\
\hline & & W & 1 & & 1.05 & \\
\hline \multirow[t]{3}{*}{$\mathrm{m} 1$} & CGM/DPC & $\mathrm{L}$ & 3 & 1.70 & 1.74 & 1.77 \\
\hline & & Wtr & 1 & & 1.15 & \\
\hline & & Wta & 3 & 1.14 & 1.23 & 1.36 \\
\hline \multirow[t]{3}{*}{$\mathrm{m} 2$} & CGM/DPC & $L$ & 4 & 1.85 & 1.98 & 2.20 \\
\hline & & Wtr & 3 & 1.00 & 1.12 & 1.21 \\
\hline & & Wta & 2 & 1.10 & 1.17 & 1.25 \\
\hline \multirow[t]{3}{*}{$\mathrm{m} 3$} & CGM/DPC & $L$ & 4 & 1.95 & 2.09 & 2.20 \\
\hline & & Wtr & 3 & 1.25 & 1.28 & 1.30 \\
\hline & & Wta & 3 & 1.15 & 1.20 & 1.25 \\
\hline \multirow[t]{2}{*}{$\mathrm{m} 4$} & CGM/DPC & $L$ & 1 & & 2.15 & \\
\hline & & Wta & 1 & & 0.98 & \\
\hline \multirow[t]{2}{*}{ P2 } & DPC & L & 1 & & 1.60 & \\
\hline & & W & 1 & & 0.71 & \\
\hline \multirow[t]{2}{*}{ P3 } & DPC & L & 1 & & 2.01 & \\
\hline & & W & 1 & & 1.08 & \\
\hline \multirow[t]{2}{*}{ M2 } & DPC & L & 1 & & 1.94 & \\
\hline & & W & 1 & & 2.54 & \\
\hline \multirow[t]{2}{*}{ M3 } & DPC & L & 1 & & 2.14 & \\
\hline & & W & 1 & & 2.87 & \\
\hline \multicolumn{7}{|c|}{ Herpetotheriidae? } \\
\hline \multirow[t]{3}{*}{$\mathrm{m} 4$} & UM MORII & L & 1 & & 1.63 & \\
\hline & & Wtr & 1 & & 0.93 & \\
\hline & & Wta & 1 & & 0.94 & \\
\hline \multicolumn{7}{|c|}{ Kasserinotherium tunisiense } \\
\hline \multirow[t]{2}{*}{ M1 } & EY & L & 1 & & 1.60 & \\
\hline & & W & 1 & & 1.75 & \\
\hline \multirow[t]{2}{*}{ M3 } & EY & L & 1 & & 1.42 & \\
\hline & & W & 1 & & 1.55 & \\
\hline
\end{tabular}


the conventional metatherian dental formula as $1 / \mathrm{i} 5 / 4$, $\mathrm{C} / \mathrm{c} 1 / 1, \mathrm{P} / \mathrm{p} \mathrm{3/3}, \mathrm{M} / \mathrm{m} \mathrm{4/4}$, although there are other hypotheses (e.g., O'Leary et al., 2013). Measurements (Tab. 1) are in $\mathrm{mm}$.

Class MAMMALIA Linnaeus, 1758

Infraclass METATHERIA Huxley, 1880

Clade MARSUPIALIFORMES Vullo et al. 2009

Family HERPETOTHERIIDAE Trouessart, 1879

A recent phylogenetic analysis by Ladevèze et al. (2020) including dental, petrosal, and postcranial features led to the exclusion of herpetotheriids (and of peradectids) from the Didelphimorphia. Moreover, it led to the conclusion that the Herpetotheriidae as currently understood (i.e., including at least Herpetotherium, Copedelphys, Peratherium, and Amphiperatherium) is not a natural group. The authors opted to maintain the Herpetotheriidae for historical reasons, and recognized the new Subfamily Peratheriinae, within the Herpetotheriidae, for the inclusion of Peratherium and Amphiperatherium (Ladevèze et al., 2020). Here we use the family term Herpetotheriidae in its traditional concept and contents.

Genus Peratherium Aymard, 1846

Type-species. Didelphis crassum Aymard 1846. Peratherium crassum Aymard, in Gervais (1848, p. 134, 1859, p. 266). Early Oligocene; Egypt and Oman.

\section{Peratherium africanum Simons \& Bown, 1984}

Figure $2 \mathrm{~A}-2 \mathrm{D}$

Type. Right dentary fragment with $\mathrm{p} 2-\mathrm{m} 3$, roots of $\mathrm{c} 1$ and $\mathrm{p} 1$ and alveoli for $\mathrm{m} 4$ (CGM 40236) from the upper Jebel Qatrani Formation, Rupelian, Oligocene, Quarry M, Fayum Province, Egypt.

Referred specimens. Left dentary with $\mathrm{m} 2-3$ and part of m4 (CGM40237); left edentulous dentary fragment (DPC 3120); right maxillary fragment with P2-M3, roots of P1 and parts of alveoli of C1 and M4 (DPC 16946); right dentary fragment with p3-m4, two empty alveoli anterior to p3 and part of the root of p1? (DPC 3820); right dentary fragment with eroded $\mathrm{p} 3-\mathrm{m} 4$ and partial roots of c1-p2 (DPC 8201); left dp3 (TQ94).

Occurrence. Jebel Qatrani Formation, Fayum Depression, northern Egypt) and Taqah (Sultanate of Oman).

\section{Age. Early Oligocene.}

Original diagnosis. Moderately small marsupial, approximately the size of Peratherium cuvieri (Fischer, 1829) (aprox. M2, length: 2.1, width: 2.4; m2, length 2, width: 1.4). Resembles P. cuvieri and Peratherium perrierense Crochet, 1979 in having the entoconid close against the trigonid on m1-2 and connected to it by a raised wall. It resembles $P$. cuvieri and
Peratherium antiquum (Blainville, 1840) in having short m1-3 talonids. Differs from these and other species in having essentially vertical $\mathrm{m} 1-3$ hypoconulids that are as large and as tall as the entoconids. The hypoflexids of $\mathrm{m} 1-3$ are very shallow as in Peratherium perrierense Crochet, 1979 and $P$. antiquum and in contrast to $P$. cuvieri and other species. $\mathrm{m} 1<\mathrm{m} 2<\mathrm{m} 3<\mathrm{m} 4$, as in Peratherium elegans (Aymard, 1846), P. perrierense, $P$. antiquum, Peratherium bretouense Crochet, 1979, and Peratherium lavergnense Crochet, 1979, and in contrast to most other species. There is no diastema between p1-2, in contrast with all above forms excepting $P$. lavergnense; $\mathrm{p} 2$ has a distinct paraconid (anterior cusp) in contrast to all other known species of Peratherium.

Revised diagnosis by Crochet et al. (1992). Peradectidae of rather small size typified by the increasing length of the lower molars from $\mathrm{m} 1$ to $\mathrm{m} 4$. Distinguished from all other Holarctic Peradectidae by its molars with reduced talonid and with an oblique crest ending buccally against the trigonid. Presence of a diastema between $\mathrm{p} 1$ and $\mathrm{p} 2$. Molars with hypoconulid and entoconid of similar height and linked by high crests. Cusp tips of the molars worn by strong abrasion.

Revised diagnosis by Hooker et al. (2008). Mediumsized Peratherium, length of M3: $2.14 \mathrm{~mm}$. M1-3 transversely elongate with deep ectoflexus, especially on M3 where it emarginates half the width of the stylar shelf; weakly dilambdodont with metacone much larger than paracone; large, mesially placed stylar cusp $B$ confluent with cusp $A$; very small stylar cusp $C$ on the distal flank of cusp $B$; paracingulum interrupted adjacent to paracone. Lower molars with short talonid and buccally located cristid obliqua; hypoconulid large, taller than the entoconid and close to its lingual margin; shallow distolingual area of talonid, after wear becoming a curved 'crest' linking hypoconulid to entoconid (hypoconulid-entoconid talonid fold).

Discussion. Bown and Simons (1984a) described the first marsupial remains from Africa on the basis of three fragmentary mandibles from the Jebel Qatrani Formation. Even though they did not formally describe them as belonging to a new taxon, they highlighted the similarities between the African materials with the genus Peratherium. A few months later Simons and Bown (1984) formally described the anterior material as the new species $P$. africanum. This material undoubtedly belongs to a metatherian in having three premolars and four molars. These authors followed Crochet $(1977,1980)$ in referring the species to Peratherium, as the protoconid increases in height from $\mathrm{m} 1$ through $\mathrm{m} 4$; the anterior face of the metaconid is generally subvertical in lingual view; the entoconids are conical, often tall; the width of $\mathrm{m} 4$ talonid is reduced, with the hypoconulid placed equally between the hypoconid and the entoconid; the molars tend to lengthen from $\mathrm{m} 1$ through $\mathrm{m} 4$; and the talonid of $\mathrm{m} 4$ is strongly reduced. 
These authors highlighted that $P$. africanum shares all of these characters to a greater or lesser degree and discarded the genus Herpetotherium because $P$. africanum does not have its $\mathrm{m} 2$ and $\mathrm{m} 3$ of subequal length; the $\mathrm{m} 4$ is shorter than other molars; the m1-4 metaconids are nearly as tall as the protoconids, and the molar entoconids are strongly lengthened at their buccal bases. They emphasized the strong similarity of this species with $P$. cuvieri, $P$. antiquum and $P$. perrierense. The authors discussed on the European origin of this species, although Jaeger and Martin
(1984) argued on a vicariant origin of this taxon, and the possibility of it being a survivor of an ancestral marsupial stock common to South America and Africa before the opening of the South Atlantic. Bown and Simons (1984b) replied that there is no evidence to support this hypothesis involving the composition and dispersion of an unknown fauna.

A few years later Crochet et al. (1992) described a dp3 from Oman, and assigned it, in spite of its relative large size, to $P$. aff. $P$. africanum on the basis of the broadly structured cusps, high entocristid, very shallow
A

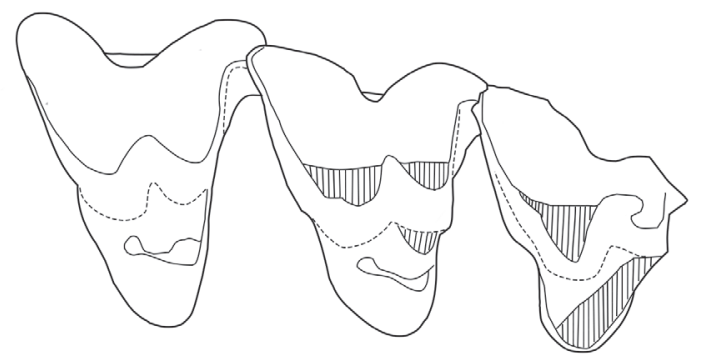

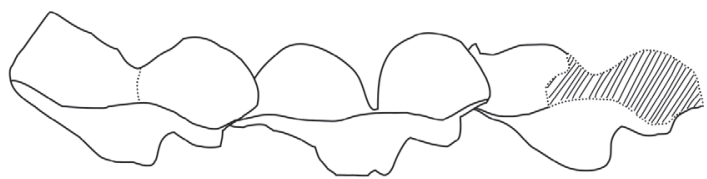

B

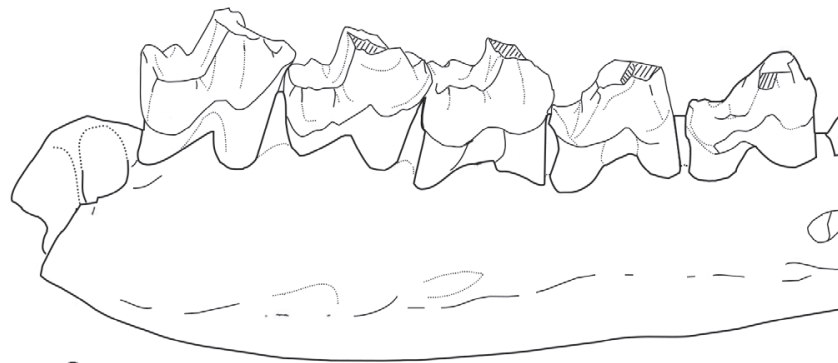

C

I

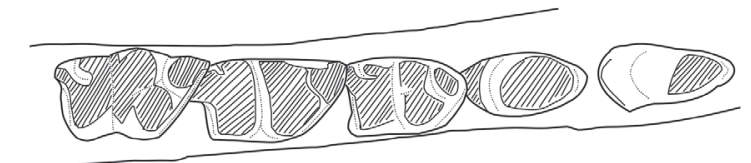

D
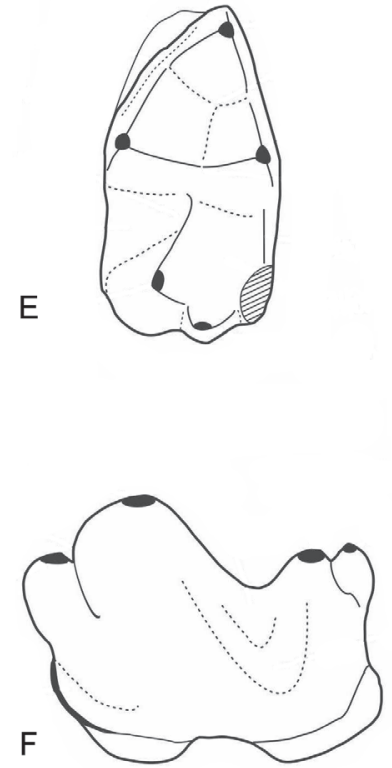

G
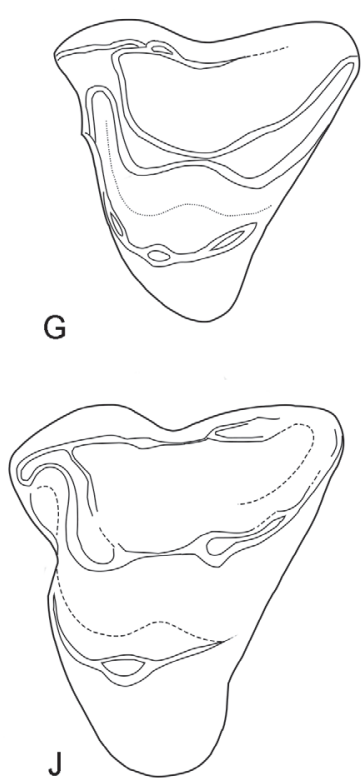

$\mathrm{H}$
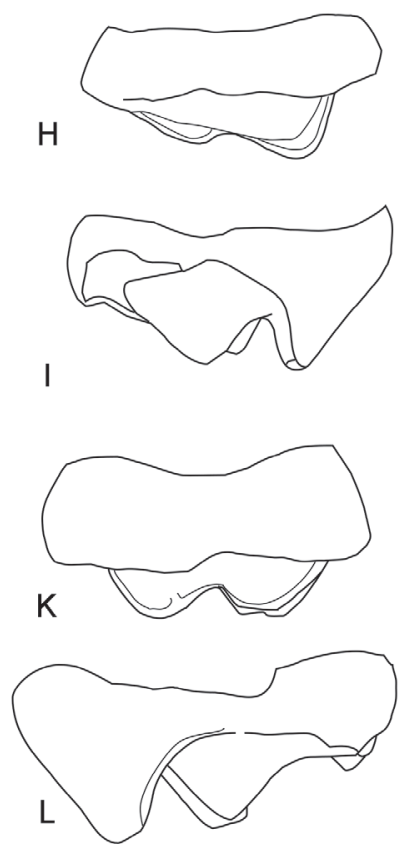

Figure 2. A-B, Peratherium africanum, DPC 16946, right maxilla with P2-M3 (M1-3 in this figure), after Hooker et al. (2008, fig. 1) in occlusal and buccal views; C-D, Peratherium africanum CGM4 0236 (holotype), right mandible showing p2-m3 in buccal and occlusal views; E-F, Herpetotheriidae? gen et sp. indet. UM MOR II 48'04, left m3 in occlusal and buccal views; G-L, Kasserinotherium tunisiense; G-I, EY 10, holotype, a left M3 in occlusal, buccal, and anterior views; J-L, EY 12, right M1 (inverted drawing) in occlusal, buccal, and anterior views, after Crochet (1986, figs. 1, 2); scale bar = $1 \mathrm{~mm}$. 
hypoflexid, the cristida obliqua ending buccally against the trigonid wall, the well-cuspate hypoconulid, the entoconid linked to the hypoconulid by a high crest, and the strongly abraded tip of the cusps. The authors noted that the assignment of this species to the genus Peratherium was very weak (mostly based on the increasing length of the lower molars); moreover, they argued that some features of the original diagnosis are typical of the Peradectidae: hypoconulid and entoconid of similar height, and occurrence of a high crest linking the entoconid. In consequence, they described Qatranitherium as a new genus of peradectid. With this new classification, these authors emphasized the ancient origin of the Afro-Arabian marsupials, independent of the more recent immigrations of the European taxa. Later McKenna and Bell (1997), following Simons and Bown (1984), regarded the genus as synonymous with the herpetotheriine Peratherium.

Hooker et al. (2008) described new materials including a near complete maxilla from the type locality, and placed this species in the genus Peratherium on the basis of the following features: the morphology of the upper molars is clearly herpetotheriid by its dilambdodonty and enlarged metacone; the crest linking the lower molar hypoconulid to the entoconid is not the lingual branch of the postcristid as in Peradectes; the appearance of an entocristid is enhanced by the advanced wear state and the proximity of the entoconid to the metaconid (as it happens in several species of Peratherium); a buccally positioned cristid obliqua (typical of Peradectes and several species of Peratherium); and in that the hypoconulid is located near the lingual margin of the tooth, while it is more buccally placed in peradectids.

\section{Family HERPETOTHERIIDAE?}

\section{Genus and species indet.}

Figure 2E-2F

Material. UM MOR II 48'04, an ultimate lower left molar.

Occurrence. Moroto II locality, north of Nakiloro Village, Moroto District, northeastern Uganda. Kogole Beds (Miocene valley infillings east and south of Kogole Hill).

Age. Late early Miocene, upper Burdigalian.

Discussion. Pickford and Mein (2006) described UM MOR II 48'04 as an m1 or m2, and argued that the specimen belongs to a possible marsupial, rejecting the idea that it is referable to the Tenrecidae or Chrysochloridae on the basis of the number of the cuspids in the talonid. Taking that into account, besides the highly specialized Anatoliadelphyidae, until now only two families of marsupialiform metatherians are present in the Cenozoic of the Old World, Peradectidae and Herpetoteriidae. The first can be discarded because of the presence of a postentocristid in the lower molars (a diagnostic feature of the Peradectidae; Ladevèze et al., 2012; Smith \& Smith, 2013). On the contrary, in herpetotheriids there is a notch between the entoconid and the hypoconulid, as is the case of specimen UM MOR II 48'04. We also note that herpetotheriids have hypoconulids and entoconids of unequal height (the entoconid is higher in $\mathrm{m} 1-3$, but not in $\mathrm{m} 4$ ) while in peradectids entoconids and hypoconulids are of similar height in all lower molars, including the m4 (Crochet, 1979, 1980). Even though the entoconid is broken in the UM MOR II 48'04, it is clear that the hypoconulid was a larger cusp. In summary, the African specimen most probably belongs to the Herpetotheriidae, being impossible to refer it to any known taxon of this family.

\section{Superfamily ?PERADECTOIDEA \\ Genus Kasserinotherium Crochet, 1986}

Type-species. Kasserinotherium tunisiense Crochet, 1986. Early Eocene, Tunisia.

\section{Kasserinotherium tunisiense Crochet, 1986}

Figure 2G-2L

Type. EY 10, left M3.

Referred specimens. EY 12, right M1.

Occurrence. Kasserine locality area, Chambi Massif, central Tunisia. Basal levels of "Couches Rouges", Chambi Massif.

\section{Age. Early Eocene.}

Original diagnosis (after Crochet, 1986, translated from French). Small peradectine; upper molars have stylar cusps that are not very distinct; StA is supported by a spur clearly anterior to the rest of the crown and not separated from StB by a notch; the preparacrista meets the apex of StB; the centrocrista is not deeply indented between the paracone and the metacone; the protofossa is significantly lengthy; the lingual base of the protocone slightly tilted posteriorly; conules absent.

Discussion. Crochet (1986) described two upper molars from the early Eocene of Chambi as belonging to a new genus of peradectine metatherian. He regarded them as belonging to a marsupial because of the presence of a line of stylar cusps and a large stylar area, together with the absence of a hypocone and of a cingulum below the protocone, and by the presence of a rectilinear centrocrista with a predilambdodont morphology. Following previous definitions and concepts (e.g., Crochet, 1980) he regarded the new taxon as belonging to Peradectinae (see also Crochet et al., 2007), noting similarities between Kasserinotherium and Peradectes, Mimoperadectes and Alphadon (Crochet, 1986). A later phylogenetic analysis placed this genus as sister-taxon to the early Oligocene, Chinese peradectid Junggaroperadectes (Maga, 2008). Other authors doubted the metatherian nature of Kasserinotherium: without further arguments, 
McKenna and Bell (1997, p. 49) regarded this genus as an indeterminate Theria, while Van Couvering and Delson (2020) included it within their "Placentalia indet." Finally, Gunnell (2010) noted that because of the primitive, simple nature of these materials (both upper molars), there is no convincing reason to believe that Kasserinotherium represents a marsupial (i.e., a metatherian in the current concept of this marsupialiform group).

Contra Gunnell (2010) we regard the upper molar pattern of Kasserinotherium neither "primitive" nor "simple". On the contrary, it displays a unique mixture of generalized and derived features: straight centrocrista, wide stylar shelf, preprotocrista ending at the parastylar corner of the tooth, reduced protocone, lack of conules, relatively long postmetacristae, labiolingually compressed stylar cusps. This combination of features is suggestive of faunivorous feeding habits (see also Beck, 2013, and below).

On the basis of the available evidence we agree with Crochet's original thoughts on the metatherian nature of Kasserinotherium. We discard roughly similar placental mammals as primitive afrosoricids (after Seiffert, 2010a) because of the absence of metaconule, a relative narrow tooth, the more developed postero-buccal side of the tooth and the shorter pre- and postprotocrista. However, we doubt its peradectid (s.s.) affinities. When Crochet (1986) considered the affinities of Kasserinotherium, his only sources of comparisons among European marsupialiforms were the "Peradectini" (Peradectidae) and the "Didelphini" (actually, the Herpetotheriidae). As peradectids have a straight centrocrista, while herpetotheriids have a v-shaped one, he was confident on the peradectid nature of Kasserinotherium. However, there are a number of metatherian lineages that keep the plesiomorphic condition of a straight centrocrista: "alphadontids", stagodontids, pediomyids, etc. (see, e.g., Kielan-Jaworowska et al., 2004). Even among didelphimorphians, several taxa have straight centrocristae in part or all the upper molar series (Goin, 1997).

Goin and Candela (2004) suggested affinities between Kasserinotherium and Wirunodon chanku Goin \& Candela, 2004 (Marsupialiformes, Order and Family indet.), from the Paleogene (late Eocene?) of Santa Rosa local fauna in the Peruvian Amazonia. Both taxa are strikingly similar in having a "...very small size, straight centrocrista, conules absent, reduced protocone and trigon fossa, reduced and labiolingually compressed stylar cusps, wide stylar shelf, and welldeveloped postmetacrista..." (Goin \& Candela, 2004, p. 43). In turn, Beck (2013) noted similar dental features shared by Kasserinotherium, Wirunodon, and Archaeonothos henkgodthelpi Beck, 2013, from the early Eocene Tingamarra fauna of southern Queensland, Australia. He stated that the last species differs from Kasserinotherium and Wirunodon in having a larger size, a more mesial-posteriorly compressed protocone, a larger differential height between the paracone and the metacone, larger StB, smaller StD, while the preparacrista ends at StB rather than StA. Both Goin and Candela (2004) as well as Beck (2013) noted several features suggestive that all these taxa could be referred s.l. to the Peradectidae; however, their distinctive combination of derived and generalized features was noticeable enough to not refer them to any known family of marsupialiform metatherians. Part of the problematic nature of this topic is the radically different geographical provenances of the involved taxa: Kasserinotherium comes from northwestern Africa, Wirunodon from western Amazonia in South America, and Archaeonothos from southern Queensland in eastern Australia. Any hypothesis linking these three taxa should give a convincing biogeographic response to such disparate provenances (see below). What seems clear to us is that, even though Kasserinotherium (and Wirunodon and Archaeonothos as well) does not belong to the Peradectidae s.s., they may be part of an early (Paleocene?; see below) peradectoid off shoot exclusive to the southern continents.

Infraclass EUTHERIA Huxley, 1880

Family ZHELESTIDAE Nesov, 1985

Gen. et sp. indet.

Figure 3A-3B

Specimen. An isolated, fragmentary lower molar (UA 8699).

Occurrence. Locality MAD93-35, Mahajanga Basin, Northwestern Madagascar. Anembalemba Member of the Maevarano Formation.

\section{Age. Latest Cretaceous (Maastrichtian).}

Discussion. Krause (2001; see also Case \& Krause, 2002) referred specimen UA 8699 to the Metatheria because of several features: presence of a prominent distobuccal cingulid extending from the base of the hypoconid towards the hypoconulid apex; the hypoconulid is lingually placed, well away from the hypoconid; the talonid is at least as broad as the trigonid; the trigonid is low; finally, wear is mostly horizontal. Averianov et al. (2003) argued that these same features also appear among zhelestid eutherians, and highlighted the similarities between specimen UA 8699 and lower molars of the spanish zhelestid Lainodon orueetxebarriai. An indirect clue of the possible affinities of UA 8699 and Lainodon is that both sites have faunistic similarities including snakes, dinosaurs and turtles, although the origin of the Madagascar fauna is largely discussed (see Rage, 2003 and references therein). Later, Krause (2013) maintained his arguments on the metatherian nature of this specimen, while Archibald and Averianov (2012) kept on regarding it as a Zhelestidae indet. The fact that the only specimen at hand from the Late Cretaceous of Madagascar is a lower, worn, broken molar, does not 
help in clarifying its taxonomy. Our own observations on the figured materials and original descriptions led us to tentatively agree with Averianov et al. (2003) suggestion that it most probably belongs to a zhelestid eutherian mammal.

Clade EUARCHONTA Waddell et al.,1999

Family ADAPISORICULIDAE Van Valen, 1967

Genus Garatherium Crochet, 1984

Type-species. Garatherium mahboubii Crochet, 1984. Early Eocene, Algeria.

\section{Garatherium mahboubii Crochet, 1984}

Figure $3 \mathrm{C}-3 \mathrm{~F}$

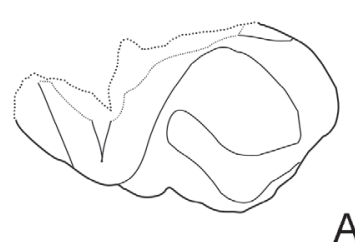

A
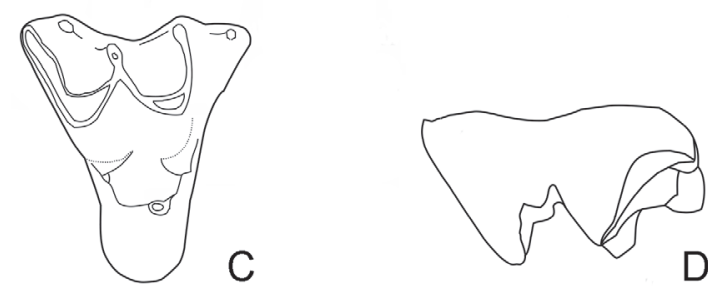

Type. Uncatalogued specimen, originally referred to a right M3 (our interpretation: a right M2).

Referred specimens. The type only.

Occurrence. Brézina region, South Oran, El Kohol (Locus B), Algeria; "...membre marno-calcaire de la formation d'El Kohol..." (Crochet, 1984, p. 277).

Age. Late early Eocene (Ypresian).

Original diagnosis (translated from French). Peradectine of very small size with an enhanced, didelphid-like dilambdodonty in the upper molars; StB only slightly lower than the paracone and much larger than StA; StC placed on the buccal edge of the molar

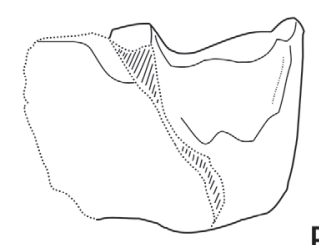

$B$

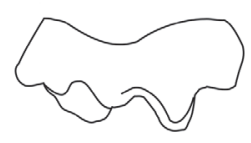

E

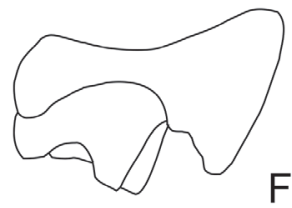

$\mathrm{F}$

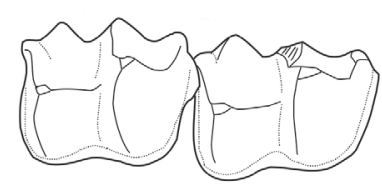

G

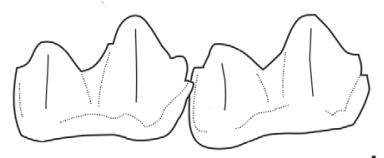

$\mathrm{H}$
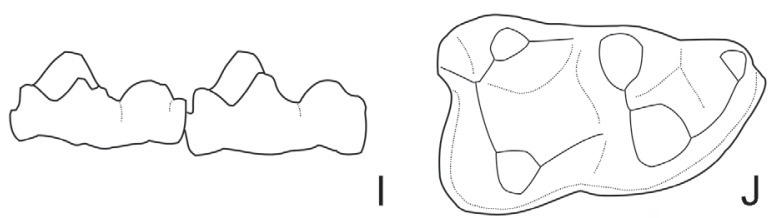
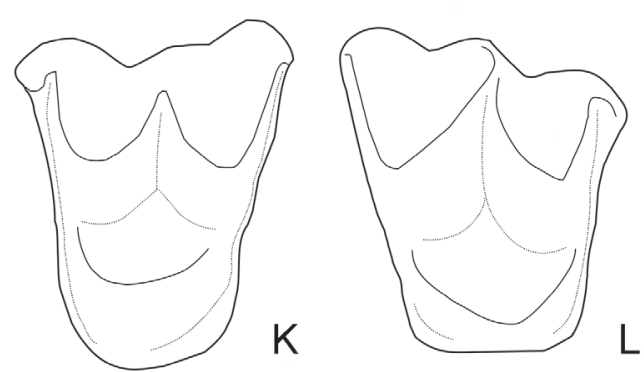

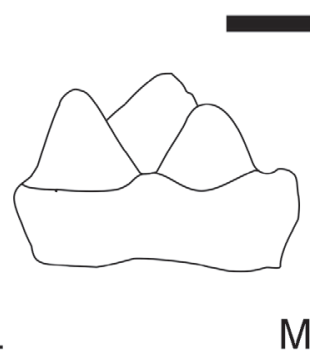

L

M

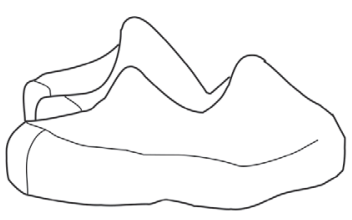

$\mathrm{N}$

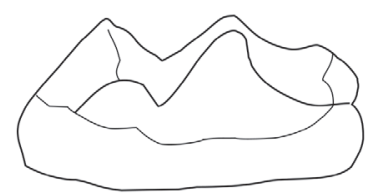

Figure 3. A-B, Zhelestidae gen. et sp. indet., UA 8699, fragment of lower molar in occlusal and buccal views, after Krause (2001, fig. 1A and 1E); C-F, Garatherium mahboubii, right M2 in occlusal, anterior, buccal, and posterior views, after Crochet (1984, fig. 1); G-I, Ghamidtherium dimaiensis, CGM 83699, right m1-2 in occlusal, buccal and lingual views, after SánchezVillagra et al. (2007, fig. 1B-D); J, Chiroptera indet., DPC 21498B, right m?1 in occlusal view, after Sánchez-Villagra et al. (2007, fig. 1E); K-O, ?Khonsunycteris or ?Phasmatonycteris or new genus and species; K, DPC 21372A, left M1 in occlusal view; L-O, DPC 21372B, M2 in occlusal, buccal, anterior, and posterior views, after Sánchez-Villagra et al. (2007, fig. 4); scale bar = $1 \mathrm{~mm}$. 
crown; concave preparacrista, with its lower portion placed at a mid-distance from the paracone and the $\mathrm{StB}$; well-developed conules on the lingual slopes of paracone and metacone; protocone high; protofossa deep and narrow (Crochet, 1984, p. 279).

Discussion. Crochet (1984) described Garatherium mahboubii on the basis of a single upper molar from El Kohol (Algeria, lower Eocene), which had previously been referenced by Mahboubi et al. (1983). He referred it to a metatherian on the basis of the following combination of features: five distinct stylar cusps located buccally in the stylar shelf, lack of hypocone and of pre- and postcingula, wide stylar shelf, and presence of a "dilambdodontie didelphidienne" (Crochet, 1984, p. 282). In spite of its v-shaped, invasive centrocrista, he argued in favour of peradectid affinities on the basis of eight features (e.g., size of stylar cusps, length of parastylar edge, similar height of paracone and metacone, conular size, etc.). He emphasized the similarities between Garatherium and Alphadon (the latter was then regarded as a Peradectinae).

After its original description, the taxonomic history of Garatherium has been quite controversial. Mahboubi et al. (1986) maintained the considerations by Crochet (1984). Kappelman et al. (1996) regarded Garatherium as a possible marsupial, while McKenna and Bell (1997) classified it within the Herpetotheriinae. More recently Métais et al. (2018) compared G. mahboubii with a Galatiadelphys minor Métais et al., 2018, regarding the former as a purported metatherian. Gheerbrant $(1991,1995)$ reclassified Garatherium as an adapisoriculid eutherian. Gheerbrant et al. (1998) described another possible species of the genus Garatherium (?Garatherium todrae Gheerbrant et al., 1998). The genus was also regarded as part of the Adapisoriculidae by Seiffert (2010a, 2010b), who discussed the possible intermediate condition between the (older) dilambdomorphs and tenrecoids, and the possibility that this genus actually represents an early stem tenrecoid. De Bast et al. (2012) also regarded Garatherium as an adapisoriculid and considered that it probably represents a second dispersal event between Europe and Africa during the late Palaeocene. Finally, Eldridge et al. (2019) followed the same arguments of Seiffert (2010a, 2010b). Taking in account all arguments at hand, we regard Garatherium as a probable adapisoriculid eutherian.

Order ?EULIPOTYPHLA Waddell et al., 1999

Genus Ghamidtherium Sánchez-Villagra et al., 2007

Type-species. Ghamidtherium dimaiensis SánchezVillagra et al., 2007. Late Eocene, Egypt.

Ghamidtherium dimaiensis Sánchez-Villagra et al., 2007

Figure 3G-3I
Material. In the original publication: CGM 83699, a right dentary fragment including $m ? 2-3$, and alveoli for $m ? 4$ and a partial first lower molar (m?1), preserving the trigonid and about half of the talonid (DPC 22442D). Our interpretation of the mandible: a right dentary fragment including $\mathrm{m} 1-2$ and the alveoli of $\mathrm{p} 4$ and $\mathrm{m} 3$.

\section{Occurrence. BQ-2 Quarry, Fayum Depression, Egypt.}

Age. Late Eocene (Priabonian).

Original diagnosis. Ghamidtherium differs from other Paleogene Afro-Arabian mammals in combining the following features: molar trigonids relatively open and uncompressed, with a large angle between the proto and paracristids that decreases distally; molar metaconids low relative to protoconids, slightly taller than paraconids; lingually situated hypoconulid relatively small, connected to hypoconid (nyctalodont); weak buccal cingulids that are restricted to hypoflexids; well-developed precingulids; tooth mesial to the $m ? 2$ relatively large (about $90 \%$ the length of the $\mathrm{m} ? 2$, based on spacing of alveoli), with mesial alveolus not offset buccally with respect to the distal alveolus.

Discussion. On the basis of a mandible with two molars and an isolated lower molar (probably belonging to the same species) from Fayum (Quarry BQ-2, Egypt, earliest late Eocene), Sánchez-Villagra et al. (2007) recognized the species Ghamidtherium dimaiensis; in the same publication they also described two upper molars regarded as Mammalia indet. and discussed their probable belonging to Marsupialia or Chiroptera. We discuss all these specimens in the following sections.

Sánchez-Villagra et al. (2007) argued that the lower molars have marsupial-like features, as the large size of the tooth mesial to $m ? 2$, and that the alveoli before the $m ? 2$ belongs to an elongated tooth, probably one molar, because both features do not appear (to them) in Paleogene bats. They highlighted the twinning of the hypoconulid and entoconid as typical of marsupials, though they are present in many bats (nyctalodonty) and in several Eulipotyphla, as the soricids. They stressed that the Paleogene bats from Afro-Arabia are myotodont, an exception being the oldest philisid Dizzya, which is nyctalodont. Regarding the upper molars, they emphasised that they could be referred to, but not diagnosed as, Marsupialia because of the absence of a hypocone, presence of $\mathrm{StC}$, a relatively low paracone, and the moderately slender lingual portion of the upper molars. Simmons et al. (2016) questioned the whether these materials pertain to a marsupial. Subsequently, Eldridge et al. (2019) argued that Ghamidtherium dimaiensis could actually be a bat.

Our interpretation of the mandible and the lower tooth is that they belong to two different species: they have quite different, distinct postcristids, one high and 
straight ending in a small hypoconulid near to the entoconid, while in the isolated tooth there is a v-shaped postcristid in lateral view; in turn, the hypoconulid is well-developed and attached to the postcristid near the middle portion of the tooth. Other small differences (also highlighted by Sánchez-Villagra et al., 2007) are the more developed protoconid (and less developed metaconid and paraconid) and the small entoconid in the mandibular teeth. The interpretation of the mandible and the two molars as $m ? 2$ and $m ? 3$ by SánchezVillagra et al. (2007) was based in the supposed absence of an elongated p4 among Paleogene chiropterans. However, some Palaeochiropterygidae as Anatolianycteris insularis from the middle Eocene of Turkey actually have an elongated p4 (Jones et al., 2019), as it also happens in the Archaeonycteridae Archaeonycteris? storchi Smith et al., 2007 from the early Eocene of India (Smith et al., 2007). In addition, the morphology of the mandible is not characteristic of bats: in this group, the lower jaw may be either long in primitive forms (see, e.g., Novacek, 1987; Gunnell \& Simmons, 2005) or short in more advanced taxa, but the basal section is always straight; on the contrary, in Ghamidtherium is curved as in the Eulipotyphla or the Afrotheria, even though the morphology of the teeth is more similar to that of the former. Summarizing, taking in account all evidence at hand, we suggest that specimen CGM 83699 may represent an indetermined Eulipotyphla.

Order CHIROPTERA Blumenbach, 1779

Chiroptera indet.

Figure 3J

Material. In the original publication (Sánchez-Villagra et al., 2007): one tooth anterior to m?1 (DPC 21498B).

Occurrence. BQ-2 Quarry, Fayum Depression, Egypt.

Age. Earliest late Eocene (Priabonian).

Discussion. Sánchez-Villagra et al. (2007) described an isolated lower molar from Fayum (Quarry BQ-2, Egypt, earliest late Eocene) possibly belonging to the

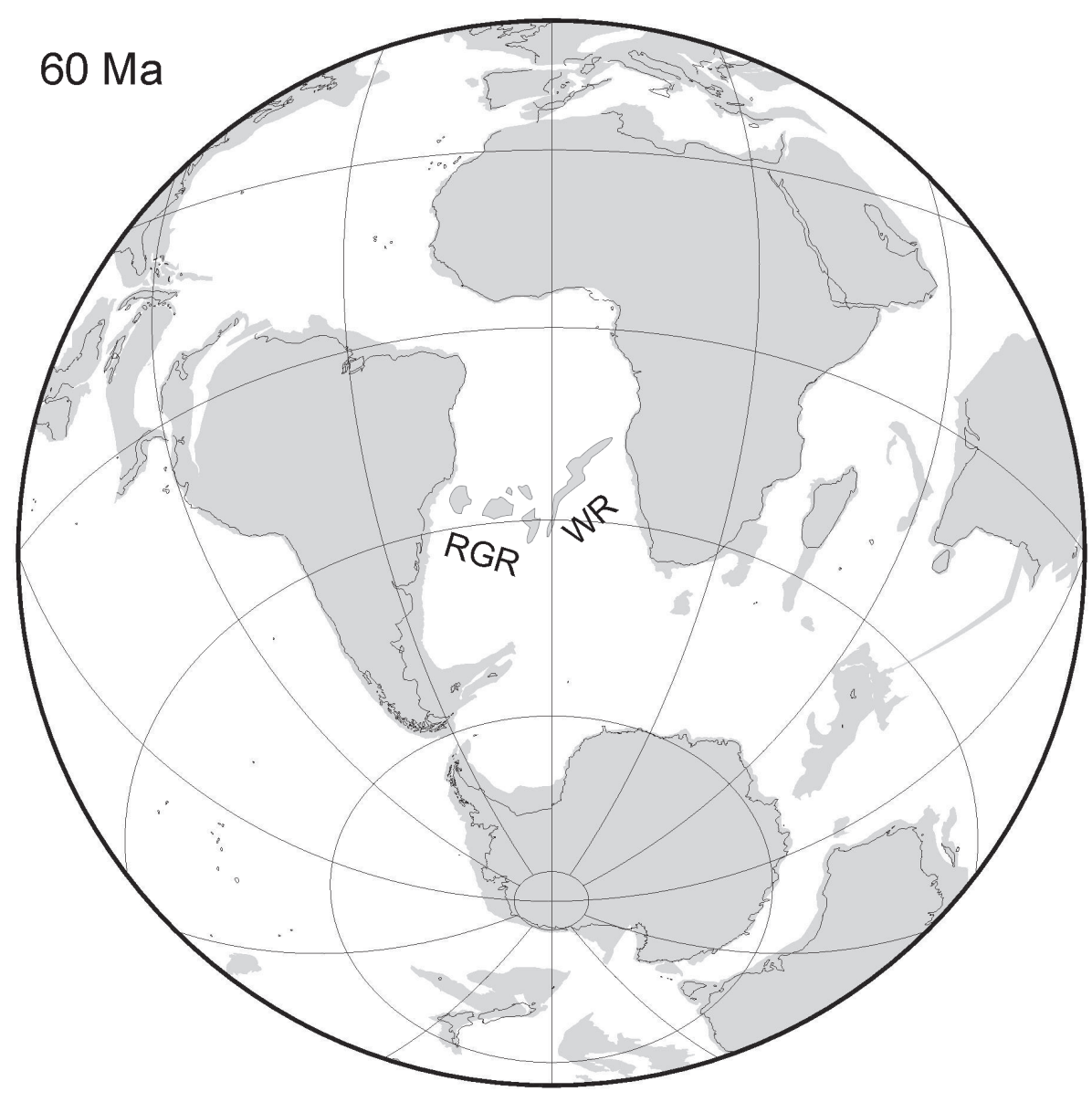

Figure 4. Position of the southern continents at $60 \mathrm{Ma}$. The palaeogeographic reconstruction was performed with the palaeomap maker of ODSN (Ocean Drilling Stratigraphic Network) Plate Tectonic Reconstruction Service (Research Center for Marine Geosciences / Kiel and the Geological Institute of the University Bremen; https://www.odsn.de/odsn/services/paleomap/ paleomap.html). Projection: Lambert Azimuthal. Present day shorelines are in black. To the resulting palaeomap we added the contours of the Rio Grande Rise (RGR) and Walvis Ridge (WR) in the South Atlantic. 
species Ghamidtherium dimaiensis, and discussed the possibility of it belonging to the Marsupialia or Chiroptera. We argued before that this tooth belongs to a different taxon (see above). Actually, the isolated tooth DPC 21498B may belong to a chiropteran, as it closely resembles the morphology described for the lower molars (necromantodonty sensu Maitre, 2014). Such a talonid morphology is present until the earliest Eocene (Maitre, 2014). The size of the tooth is relatively large for a bat; notwithstanding, similar sizes are found in Eocene philisids as Witwatia (Gunnell et al., 2008; Ravel et al., 2012).

\section{Family VESPERTILIONIDAE Gray, 1821 or} MYZOPODIDAE Thomas, 1904

?Khonsunycteris or ?Phasmatonycteris or new genus and species

Figure 3K-3O

Material. In the original publication, Mammalia indet. described by Sánchez-Villagra et al. (2007), DPC 21372A (fig. 4A), an isolated left upper molar (M?2) and DPC 21372B (fig. 4B, 4C), an isolated right upper molar (M?3). Our interpretation: DPC21372A is a M2 and DPC 21372B is a M1.

\section{Occurrence. BQ-2 Quarry, Fayum Depression, Egypt.}

Age. Late Eocene (Priabonian).

Discussion. After recognizing Ghamidtherium dimaiensis from Fayum (Quarry BQ-2, Egypt, earliest late Eocene), Sánchez-Villagra et al. (2007) described two upper molars and regarded them as Mammalia indet.; they discussed the possibility that they could belong either to the Marsupialia or to the Chiroptera. They emphasised that the upper molars can be referred to, but not diagnosed as, Marsupialia, because of the absence of a hypocone, presence of a stylar cusp C, the relatively low paracone, and the moderately slender lingual portion of the upper molars. Simmons et al. (2016) questioned the belonging of these materials to a marsupial.

In the same quarry where Ghamidtherium was found, four species of Chiroptera were recognized later: Witwatia schlosseri Gunnell et al., 2008, Witwatia eremicus Gunnell et al., 2008, Qarunycteris moerisae Gunnell et al., 2008 and Phasmatonycteris butleri Gunnell et al., 2014 (Gunnell et al., 2008, 2014). The materials described by Sánchez-Villagra et al. (2007) either differ from these species or are not comparable because they were recognized on the basis of lower molars.

To us, the upper molars described in Sánchez-Villagra et al. (2007) have several features that characterize chiropteran species of the Vespertilionidae and Myzopodidae, as Myotis, Pipistrellus or Miostrellus, in the former, or Myzopoda in the second. These features include the shape of the protocone, absence of talon, well-developed mesial and posterior cinguli, M2 having a small hypocone, among other features (Gunnell et al., 2014; Crespo et al., 2018, 2020). Notwithstanding, these materials also have unique features, as the connection of the preprotocrista with the paracone, which is disconnected to the paracingulum. While the M1 has a small hypocone that disconnects the postptotocrista to the metacone, in the M2 this appears connected to the metacone, similar to Miostrellus aff. petersbuchensis Rosina \& Rummel, 2012 described by Crespo et al. (2020). This combination of features does not appear in other vespertilionid or myzopodid bats from the Eocene. Furthermore, Gunnell et al. (2008) described a new vespertilionid genus and species (Khonsunycteris aegypticus Gunnell et al., 2008) from the Quarry L-41 from a nearly complete mandible. The age of this quarry is latest Eocene, while the quarry where Ghamidtherium was found (BQ-2) has been dated as early late Eocene. Judging from the sizes of the teeth, the upper molars are slightly larger, but could be included within the variability of Khonsunycteris aegypticus. Until upper molars of Khonsunycteris are found, we do not discard that the upper molars found in BQ-2 belong to the genus Khonsunycteris. More recently Gunnell et al. (2014) described from the same quarry of Ghamidtherium the myzopodid bat Phasmatonycteris phiomensis on the basis of a lower jaw. We question the taxonomic assignment of this species because it is quite smaller than the material described by Sánchez-Villagra et al. (2007); however, it shouldn't be discarded a referral to the same genus, or even family, until upper molars of Phasmatonycteris are found.

\section{DISCUSSION}

Hooker et al. (2008) stated that only two genera were uncontested African metatherians: the herpetotheriid Peratherium africanum and the ?peradectoid Kasserinotherium tunisiense. Here we reach the same conclusions, with the addition of a still undescribed ?herpetotheriid from the Miocene of Uganda, previously unknown. All other alleged metatherians described up to now are, to us, more probably eutherian mammals. To Hooker et al. (2008) Peratherium africanum is closer to $P$. lavergnense than to any other species of the genus. Both species share a mesiobucally directed M3 parastyle in the upper molars, while in the lower ones the hypoconulid is lingually placed and have a hypoconulid-entoconid talonid fold. The next closer species are $P$. cuvieri, $P$. elegans and $P$. antiquum; in all these species the metacone is more than twice as tall as the paracone, there is a crest that links StA and StB, a weak StC and, in the lower molars, the talonids are shorter than the trigonids. All these species are strictly European in their distribution. In turn, Kasserinotherium tunisiense is closer to Wirunodon chanku (?late Eocene of South America) and Archaeonothos henkgodthelpi (earliest Eocene of Australia) than to any other 
peradectoid marsupialiform so far known (see above for a detail of shared characters). The biogeographic implications of the implied affinities of both African metatherians are discussed below.

A first impression of this review is that metatherians were extremely scarce throughout the Cenozoic in Afro-Arabia, especially taking in account their success in other southern continents, as South America and Australia. It could be argued that there still exists a sampling bias, both geographically (findings of metatherian specimens are mostly restricted to the north of Afro-Arabia) as well as in specimen numbers. However, it should be mentioned that the (still scarce) evidence at hand contradicts this argument. The rich mammalian assemblages recovered from Lutetian levels in Sperrgebiet, Namibia, in southern Africa, led Pickford et al. (2008) to recognise 15 species, all of them eutherians. Moreover, they concluded that the Sperrgebiet mammals show close affinities with north African lineages, which argues against major biogeographic differences among Paleogene African mammals. On another line of reasoning, Cifelli and Davis (2003) discussed the Late Cretaceous, strikingly different patterns of diversification between eutherians and metatherians in North America and Eurasia. Eutherians dominated the mammalian assemblages in Eurasia throughout the Late Cretaceous, while in North America they were absent during most of this period. "Clearly, the relative successes of the two groups differed widely on the two continents. Yet, the early representatives of both groups seem to have been highly similar ecologically-most were small, insectivorous, and probably nocturnal. This puzzle remains to be resolved." (Cifelli \& Davis, 2003, p. 1900). We suggest that Cenozoic Afro-Arabian metatherians may have faced a similar situation than that of Eurasia during Late Cretaceous times: their arrival happened in a continent with a well-established diversity of eutherians filling similar ecological niches.

\section{Dual origin of african metatherians?}

As argued below, most probably metatherians did not originate in Africa, but instead dispersed to it at some time in the Late Cretaceous-early Paleogene. A thorough review of African paleogeographic, biogeographic and biotic relationships was given by Gheerbrant and Rage (2006). These authors conclude that, even though a former Gondwanan continent, after the separation of Africa and South America by mid-Cretaceous times, most biotic interchanges of the former continent were with Laurasian ones. "Isolation was broken intermittently by the establishment of discontinuous, filter routes that linked Africa to other continents. These filters permitted rare interchanges between Africa and some other Gondwanan continents (Madagascar, South America, and perhaps India), but mainly between Africa and Laurasian areas." (Gheerbrant \& Rage, 2006, p. 241).
Discussing the geographic origins of Peratherium africanum Simons and Bown (1984, p. 546) suggested five possibilities: “...(1) they were indigenous to Africa; (2) they arrived in Africa via the sweepstakes route from South America; (3) they reached Africa from North America by way of Europe; (4) they made their way by land bridge or a sweepstakes path directly from Europe; or (5) by land bridge and/or sweepstakes route(s) from Asia or Europe via Asia". On the same topic, Jaeger and Martin (1984, p. 379) suggested that a vicariant origin for the African marsupials should not be excluded, implying "...the survival of an ancestral stock common to South America and Africa before the opening of the South Atlantic". However, taking in account the timing of the opening of the South Atlantic, as well as the evolution of Cretaceous Marsupialiformes, it is clear than neither a Peratherium or a Kasserinotherium lineage were even remotely present by mid-Cretaceous times (see, e.g., Williamson et al., 2014). More recently Hooker et al. (2008) expressed few doubts on the European origins of Peratherium. In an attempt to date its arrival into AfroArabia, they (Hooker et al., 2008, p. 644) suggested that "...The most likely time for dispersal would have been during the low sea level at the time of the Oi-1 glaciation (c. 33.7-33 Ma)"; i.e., by the early Oligocene. The presence of Kasserinotherium tunisiense in the early Eocene of northern Africa casts one additional question on the ultimate origins of Afro-Arabian metatherians: did all of them arrive from the same continent(s)? The fact is that Kasserinotherium, even though belonging to a ?peradectoid stock, is distinct enough from any European peradectid in such a way that it suggests that there may be equally reasonable alternatives to that of a European (or even Holarctic) origin. In the following paragraphs we discuss each alternative considered by Simons and Bown (1984), both for Kasserinotherium and for Peratherium.

The idea that metatherians are indigenous to Africa is unsustainable on the basis of the known fossil record. There are no Mesozoic or Paleocene remains of a single metatherian from the whole continent. It is probable that more sampling efforts may give new evidences on the early Paleogene distribution of these mammals in Africa, but the possibility of a Mesozoic record is, to say the least, remote.

One hypothesis that deserves attention is a North American origin of African metatherians via Europe. The discovery of the herpetotheriid Maastrichtidelphys meurismeti Martin et al., 2005 in the latest Cretaceous of the Netherlands led Martin et al. (2005) to postulate a trans-Atlantic, high-latitude dispersal route from North America to Europe by the end of the Mesozoic. A further speculation would be that metatherians arrived to Africa from Europe by early Paleogene times, e.g., during the Paleocene. It should be noted, however, that Maastrichtidelphys shows closer affinities to North American herpetotheriids (Nortedelphys; Martin et al., 2005) than to any European one. This means that North 
American immigrant lineages of Marsupialiformes probably disappeared during the $\mathrm{K}-\mathrm{Pg}$ mass extinction. On the other hand, except for a few records from the latest Paleocene (PETM; see, e.g., Hooker, 2018) there is no Paleocene record of Metatherians in Europe, and from the early Eocene onwards all European marsupialiforms are distinct enough from their North American counterparts that Ladevèze et al. (2020) recognized the Subfamily Peratheriinae for their inclusion. Taking into account that Europe is a quite well-sampled continent for micromammals, it does not sound reasonable to suppose an endogenous (strictly European), Paleocene evolution of herpetotheriids whose record is still to be found. This same argument also goes against other alternatives postulated by Bown and Simons (1984b), i.e., that metatherians arrived in Africa from Europe by land bridge or a sweepstakes path.

As mentioned, a fourth alternative is the arrival of metatherians to Africa by land bridge and/or sweepstakes route(s) from Asia or Europe via Asia. Against this hypothesis is the fact that the diversity of both herpetotheriids and peradectids in all the Cretaceous-Cenozoic record of Asia is extremely scarce. It sounds more logical to infer dispersals between Africa and Europe than with Asia.

A final alternative is that (at least some) metatherians arrived in Africa via a filter route from South America. Taking in account the probable affinities of Kasserinotherium tunisiense, we think that this possibility is the most reasonable at hand. Several filter corridors (island chains) between Africa and South America have been recognized, mainly in the South Atlantic, the most prominent ones being the Rio Grande Rise (east of Brazil) and the Walvis Ridge (west of southern Africa) system (see, e.g., Oliveira et al., 2009 and literature cited). These filter corridors would have been active during the Late CretaceousPaleogene span (Fig. 4). The Walvis Ridge (East of Namibia in Africa) and the Rio Grande Rise (East of Brazil in South America) are "... the two most prominent bathymetric features in the South Atlantic Basin (...) [They form] a V-shaped pair of volcanic lineaments whose axis of symmetry is the South Atlantic spreading center" (O'Connor \& Duncan, 1990, p. 145). To Oliveira et al. (2009) these paleogeographic features (now underwater) may have constituted a continuous land bridge between both continents previous to $50 \mathrm{Ma}$; even after $50 \mathrm{Ma}$ they conformed a series of islands that considerably shortened the distance between them. For this reason, they argued that the Walvis Ridge-Rio Grande Rise was the disperal route of plathyrrine primates and caviomorph rodents from Africa to South America. Among vertebrates, other examples of Late Cretaceous migrations between both continents include cichlid fishes, ratite birds, parrots, and geckos (see Oliveira et al., 2009 and literature cited). Some lineages of vertebrates from the Eocene of Europe that have South America affinities also seem to have dispersed through a trans-African route: ceratophryid anurans, boine and tropidolophiid snakes, and non-flying birds as Phororhacidae and Idiornithidae (see Rage \& Rocek, 2007 and literature cited). A Paleocene dispersal of metatherians from South America to Africa could not only account for the inferred affinities of Kasserinotherium but also for the presence of anatoliadelphyid polydolopimorphians (Anatoliadelphys, Orhaniyeia) in the middle Eocene of Central Anatolia (Turkey). Interestingly, Métais et al. (2018) found phylogenetic affinities between anatoliadelphyids and South American and Australian bunodont polydolopimorphian metatherians such as Palangania, Chulpasia and Thylacotinga. "We hypothesize that basal polydolopimorphians were actually present in Africa during the early and/ or middle Eocene, whence they rafted northward across Neotethys to colonize the Pontide terrane." (Métais et al., 2018, p. 15). The obvious source of the Polydolopimorphia in Africa (not yet found) is South America. A recent phylogenetic analysis by Carneiro (2019) found, in turn, affinities between Anatoliadelphys and protodidelphid didelphimorphians, a clade of endemic South American didelphimorphians very abundant in the early Eocene (Itaboraian Age). In either of both alternatives, the most parsimonious hypothesis is that of South American ancestors dispersing to Africa (we suggest, by Paleocene times) before arriving into the Pontide terrane.

A more radical hypothesis is that all European (or even Eurasian) Cenozoic Marsupialiformes have an ultimate origin in South America, from where they dispersed via Africa by the Paleocene-earliest Eocene. That is, not only the African Kasserinotherium and the Anatolian polydolopimorphians, but also the African and European (Eurasian?) Herpetotheriidae. Regarding the later, it is worth mentioning that this was already suggested previously: discussing on the origins of European herpetotheriids (their "Didelphini") Crochet and Sigé (1983) tentatively argued on a South American origin of this lineage and a trans-African dispersal to Europe (but see, e.g., Rose, 2012). Even though the known record favours a European origin of African herpetotheriids, a proper test of this hypothesis would be a phylogenetic analysis of all herpetotheriid, or purpoted herpetotheriids, so far known. On one hand, several claims have been made on the existence of South American herpetotheriids (Goin \& Candela, 2004; Oliveira \& Goin, 2012). On the other, a recent phylogenetic analysis found fundamental differences between North American and European herpetotheriids. Actually, as already mentioned, to Ladevèze et al. (2020) the Herpetotheriidae (including North American and European taxa) is not a natural group, being the European ones (Peratherium, Amphiperatherium) a clade of its own. An inclusive phylogenetic analysis would test again not only the monophyly of the group, but also the North American or South American affinities of the Peratheriinae. 
Supplementary Information. The article has no additional data.

Author contributions. V. D. C. and F. J. G. contributed equally to the design and implementation of the research, to the analysis of the results and to the writing of the manuscript. All authors approved the final version of the manuscript and agree to be held accountable for the content therein.

Competing Interest. We declare we have no competing interests.

Funding. This work was funded by the Spanish Society of Palaeontology through the help research grant 2019 (Ayudas a la investigación AJISEP-2019-07154). This research was also supported by the Argentinian Agencia Nacional de Investigaciones Científicas y Técnicas (PICT 2019-03283).

Author details. Vicente D. Crespo ${ }^{1,2}$ \& Francisco J. Goin ${ }^{1,2}$. ${ }^{1}$ CONICET, Consejo Nacional de Investigaciones Científicas y Técnicas, Argentina; ${ }^{2}$ División Paleontología Vertebrados, Facultad de Ciencias Naturales y Museo, Universidad Nacional de La Plata, Argentina. Paseo del Bosque $s / n$, B1900FWA La Plata, Argentina. vidacres@gmail.com, fgoin@fcnym.unlp.edu.ar.

Acknowledgements. Thanks are also due to the helpful comments of Cristopher Beard and Greg Wilson reviewers on the original manuscript. We thank Dr. Rodolphe Tabuce, Dr. Maeva Orliac, Dr. Pierre Antoine Olivier, Dr. Sandrine Ladevèze, and Dr. Christian de Muizon for their attention in their institution and allow us to study the remains of metatheria housed in l'Institut des Sciences de l'Evolution de Montpellier (ISEM) (Université de Montpellier, CNRS, IRD, EPHE, CIRAD, INRAP) and Muséum national d'Histoire naturelle. We also thank Dr. Martin Pickford (MNHN) for providing us with photographs of UM MOR II 48'04. V. D. C. is beneficiary of a postdoctoral fellowship from the Argentinian Consejo Nacional de Investigaciones Científicas y Técnicas (CONICET).

\section{REFERENCES}

Archibald, J. D., \& Averianov, A. (2012). Phylogenetic analysis, taxonomic revision, and dental ontogeny of the Cretaceous Zhelestidae (Mammalia: Eutheria). Zoological Journal of the Linnean Society, 164(2), 361-426. doi: 10.1111/j.1096-3642.2011.00771.x

Averianov, A. O., Archibald, J. D., \& Martin, T. (2003). Placental nature of the alleged marsupial from the Cretaceous of Madagascar. Acta Palaeontologica Polonica, 48(1), 149-151.

Aymard, A. (1846). Essai monographique sur un genre nouveau de mammifère fossile trouvé dans la HauteLoire et nommé Entelodon. Annales de la Société d'Agriculture, Sciences, Arts et Commerce du Puy, 12, 227-267.

Beck, R. M. (2013). A peculiar faunivorous metatherian from the early Eocene of Australia. Acta Palaeontologica Polonica, 60(1), 123-130. doi: 10.4202/app.2013.0011

Bi, S., Zheng, X., Wang, X., Cignetti, N. E., Yang, S., \& Wible, J. R. (2018). An Early Cretaceous eutherian and the placental-marsupial dichotomy. Nature, 558(7710), 390-395. doi: 10.1038/s41586-018-0210-3

Blainville, H. M. D. (1940). Osteographie, ou Description Iconographique composée du Squelette et du Système dentaire des Mammifères récents et fossils pour Servir de base à la zoologie ou à la géologie (1839-1864), 8 vols. Baillière.

Blumenbach, J. E. (1779). Handbuch der Naturgeschichte. Johann Christian Dieterich, Göttingen.

Bown, T. M., \& Simons, E. L. (1984a). First record of marsupials (Metatheria: Polyprotodonta) from the Oligocene in Africa. Nature, 308(5958), 447-449. doi: $10.1038 / 308447 \mathrm{a} 0$

Bown, T. M., \& Simons, E. L. (1984b). African marsupialsvicariance or dispersion? (reply). Nature, 312, 379-380. doi: 10.1038/312379b0

Carneiro, L. M. (2019). A new protodidelphid (Mammalia, Marsupialia, Didelphimorphia) from the Itaboraí Basin and its implications for the evolution of the Protodidelphidae. Anais da Academia Brasileira de Ciências, 91(2), e20180440. doi: 10.1590/0001-3765201820180440

Case, J. A., \& Krause, D. W. (2002). A tribosphenic lower molar from the Maastrichtian of Madagascar: phyletic affinities, biogeography and a new dispersal model. International Palaeo Congress, Abstract Book (pp. 31). Sydney.

Cifelli, R. L., \& Davis, B. M. (2003). Marsupial Origins. Science, 302(5652), 1899-1900. doi: 10.1126/science.1092272

Crespo, V. D., Sevilla, P., Mansino, S., Montoya, P., \& Ruiz-Sánchez, F. J. (2018). Bats from the classical site of Venta del Moro (Late Miocene, Eastern Spain). Historical Biology, 30(3), 317-326. doi: 10.1080/08912963.2016.1277995

Crespo, V. D., Sevilla, P., Montoya, P., \& Ruiz-Sánchez, F. J. (2020). A relict tropical forest bat assemblage from the early Miocene of the Ribesalbes-Alcora Basin (Castelló, Spain). Earth and Environmental Science Transactions of the Royal Society of Edinburgh, 111(4), 247-258. doi: 10.1017/S1755691020000122

Crochet, J.-Y.(1977). Lesdidelphidéspaléogènes holarctiques: historique et tendances évolutives. Geobios, 10(Mém. Spécial 1), 27-134.

Crochet, J. Y. (1979). Diversité systématique des Didelphidae (Marsupialia) européens tertiaires. Géobios, 12(3), 365378.

Crochet, J.-Y. (1980). Les Marsupiaux du Tertiaire d`Europe. Singer-Polignac.

Crochet, J.-Y. (1984). Garatheriummahboubii nov. gen., nov. sp., marsupial de l'Éocène inférieur d'El Kohol (SudOranais, Algérie). Annales de Paléontologie, 70, 275294.

Crochet, J.-Y. (1986). Kasserinotherium tunisiense nov. gen., nov. sp., troisième marsupial découvert en Afrique (Eocène inférieur de Tunisie). Comptes Rendus de l'Académie des Sciences, 302(14), 923-926.

Crochet, J.-Y., \& Sigé, B. (1983). Les mammifères montiens de Hainin (Paléocène moyen de Belgique). Part III: Marsupiaux. Palaeovertebrata, 13(3), 51-64.

Crochet, J.-Y., Thomas, H., Sen, S., Roger, J., Gheerbrant, E., \& Al-Sulaimani, Z. (1992). Découverte d'un Péradectidé (Marsupialia) dans l'Oligocène inférieur du Sultanat d'Oman: Nouvelles données sur la paléobiogéographie des Marsupiaux de la plaque arabo-africaine. Comptes Rendus de l'Académie des Sciences, 314(5), 539-544.

Crochet, J.-Y., Antoine, P. O., Benammi, M., Iqbal, N., Marivaux, L., Métais, G., \& Welcomme, J. L. (2007). A herpetotheriid marsupial from the Oligocene of Bugti Hills, Balochistan, Pakistan. Acta Palaeontologica Polonica, 52(3), 633-637.

De Bast, E., Sigé, B., \& Smith, T. (2012). Diversity of the adapisoriculid mammals from the early Palaeocene of 
Hainin, Belgium. Acta Palaeontologica Polonica, 57(1), 35-52. doi: 10.4202/app.2010.0115

Eldridge, M. D., Beck, R. M., Croft, D. A., Travouillon, K. J., \& Fox, B. J. (2019). An emerging consensus in the evolution, phylogeny, and systematics of marsupials and their fossil relatives (Metatheria). Journal of Mammalogy, 100(3), 802-837. doi: 10.1093/jmammal/gyz018

Fischer, J. B. (1829). Synopsis Mammalium. Stuttgardtiae, J.G. Cottae.

Gervais, P. (1848-1852). Zoologie et Paleontologie françaises (animaux vertébrés). 1re edition, 1859. Bertrand.

Gheerbrant, E. (1991). Bustylus (Eutheria, Adapisoriculidae) and the absence of ascertained marsupials in the Palaeocene of Europe. Terra Nova, 3(6), 586-592.

Gheerbrant, E. (1995). Les mammifères Paléocènes du Bassin D'Ouarzazate (Maroc). III. Adapisoriculidae et autres mammifères (Carnivora, ?Creodonta, Condylarthra, ?Ungulata et incertae sedis). Palaeontographica. Abteilung A, Paläozoologie-stratigraphie, 237(1-4), 39-132.

Gheerbrant, E., \& Rage, J. C. (2006). Paleobiogeography of Africa: how distinct from Gondwana and Laurasia? Palaeogeography, Palaeoclimatology, Palaeoecology, 241(2), 224-246. doi: 10.1016/j.palaeo.2006.03.016

Gheerbrant, E., Sudre, J., Sen, S., Abrial, C., \& Marandat, B. (1998). Nouvelles données sur les mammifères du Thanétien et del'Yprésien du bassin d'Ouarzazate (Maroc) et leur contexte stratigraphique. Palaeovertebrata, 27(34), 155-202.

Goin, F. J. (1997). New clues for understanding Neogene Marsupial radiations. In R. F. Kay, R. H. Madden, R. L. Cifelli, \& J. J. Flynn (Eds.), A History of the Neotropical Fauna. Vertebrate Paleobiology of the Miocene in Colombia (pp. 185-204). Smithsonian Institution Press.

Goin, F. J., \& Candela, A. M. (2004). New Paleogene marsupials from the Amazon Basin of eastern Peru. The Paleogene Mammalian Fauna of Santa Rosa, Amazonian Peru. Natural History Museum of Los Angeles County, Science Series, 40, 15-60.

Goin, F. J., Woodburne, M., Zimicz, A. N., Martin, G. M., \& Chornogubsky, L. (2016). A brief history of South American metatherians: evolutionary contexts and intercontinental dispersals. Springer.

Gray, J. E. (1821). On the natural arrangement of Vertebrose Animals. London Medical Repository, 15, 296-310.

Gunnell, G. F. (2010). Marsupialia. In L. Werdelin, \& W. J. Sanders (Eds.), Cenozoic Mammals of Africa (pp. 77-79). University California Press.

Gunnell, G. F., \& Simmons, N. B. (2005). Fossil evidence and the origin of bats. Journal of Mammalian Evolution, 12(12), 209-246. doi: 10.1007/s10914-005-6945-2

Gunnell, G. F., Simons, E. L., \& Seiffert, E. R. (2008). New bats (Mammalia: Chiroptera) from the late Eocene and early Oligocene, Fayum depression, Egypt. Journal of Vertebrate Paleontology, 28(1), 1-11. doi: 10.1671/0272-4634(2008)28[1:NBMCFT]2.0.CO;2

Gunnell, G. F., Simmons, N. B., \& Seiffert, E. R. (2014). New Myzopodidae (Chiroptera) from the Late Paleogene of Egypt: emended family diagnosis and biogeographic origins of Noctilionoidea. PLoS One, 9(2), e86712. doi: 10.1371/journal.pone.0086712

Hooker, J. J. (2018). A mammal fauna from the PaleoceneEocene Thermal Maximum of Croydon, London, UK. Proceedings of the Geologists'Association, 131(5), 458473. doi: 10.1016/j.pgeola.2018.01.001
Hooker, J. J., Sánchez-Villagra, M. R., Goin, F. J., Simons, E. L., Attia, Y., \& Seiffert, E. R. (2008). The origin of AfroArabian "didelphimorph" marsupials. Palaeontology, 51(3), 635-648. doi: 10.1111/j.1475-4983.2008.00779.x

Huxley, T. H. (1880). On the application of the laws of evolution to the arrangement of the Vertebrata, and more particularly of the Mammalia. Proceedings of Zoological Society of London, Scientific Memoirs, IV, 649-62.

Jaeger, J.-J., \& Martin, M. (1984). African marsupialsvicariance or dispersion? Nature, 312, 379. doi: 10.1038/312379a0

Jones, M. F., Coster, P. M., Licht, A., Métais, G., Ocakoğlu, F., Taylor, M. H., \& Beard, K. C. (2019). A stem bat (Chiroptera: Palaeochiropterygidae) from the late middle Eocene of northern Anatolia: implications for the dispersal and palaeobiology of early bats. Palaeobiodiversity and Palaeoenvironments, 99(5), 261-269. doi: 10.1007/ s12549-018-0338-z

Kappelman, J., Maas, M. C., Sen, S., Alpagut, B., Fortelius, M., \& Lunkka, J. P. (1996). A new early Tertiary mammalian fauna from Turkey and its paleobiogeographic significance. Journal of Vertebrate Paleontology, 16(3), 592-595.

Kielan-Jaworowska, Z., Cifelli, R. L., \& Luo, Z. X. (2004). Mammals from the age of dinosaurs: origins, evolution, and structure. Columbia University Press.

Krause, D. W. (2001). Fossil molar from a Madagascan marsupial. Nature, 412(6846), 497-498. doi: 10.1038/35087649

Krause, D. W. (2013). Gondwanatheria and? Multituberculata (Mammalia) from the Late Cretaceous of Madagascar. Canadian Journal of Earth Sciences, 50(3), 324-340. doi: 10.1139/e2012-074

Ladevèze, S., Selva, C., \& de Muizon, C. (2020). What are "opossum-like" fossils? The phylogeny of herpetotheriid and peradectid metatherians, based on new features from the petrosal anatomy. Journal of Systematic Palaeontology, 18(17), 1463-1479. doi: 10.1080/14772019.2020.1772387

Ladevèze, S., Smith, R., \& Smith, T. (2012). Reassessment of the Morphology and Taxonomic Status of the earliest Herpetotheriid Marsupials of Europe. Journal of Mammalian Evolution, 19(4), 249-261. doi: 10.1007/ s10914-012-9195-0

Linnaeus, C. (1758). Sistema naturæ per regna tria naturæ, secundum classes, ordines, genera, species, cum characteribus, differentiis, synonymis, locis, Editio decima, reformata, v. 1: Regnum animale. Laurentii Salvii.

Luo, Z. X., Ji, Q., Wible, J. R., \& Yuan, C. X. (2003). An Early Cretaceous tribosphenic mammal and metatherian evolution. Science, 302(5652), 1934-1940. doi: 10.1126/ science.1090718

Luo, Z. X., Yuan, C. X., Meng, Q. J., \& Ji, Q. (2011). A Jurassic eutherian mammal and divergence of marsupials and placentals. Nature, 476(7361), 442-445. doi:10.1038/ nature10291

Maga, A. M. (2008). Systematic paleontological investigation of the metatherian fauna from the Paleogene Uzunçarşıdere Formation, central Turkey. (PhD Thesis. University of Texas, Texas).

Mahboubi, M., Ameur, R., Crochet, J.-Y., \& Jaeger, J.-J. (1983). Première découverte d'un marsupial en Afrique. Comptes Rendus de l'Académie des Sciences, 297, 691-694. 
Mahboubi, M., Ameur, R., Crochet, J.-Y., \& Jaeger, J.-J. (1986). El Kohol (Sanaran Atlas, Algeria): A new Eocene mammal locality in North Western Africa. Palaeontographica Abteilung A, 192(1-3), 15-49.

Maitre, E. (2014). Western European middle Eocene to early Oligocene Chiroptera: systematics, phylogeny and palaeoecology based on new material from the Quercy (France). Swiss journal of Palaeontology, 133(2), 141242. doi: 10.1007/s13358-014-0069-3

Martin, J. E., Case, J. A., Jagt, J. W., Schulp, A. S., \& Mulder, E. W. (2005). A new European marsupial indicates a Late Cretaceous high-latitude transatlantic dispersal route. Journal of Mammalian Evolution, 12(3-4), 495-511.

McKenna, M. C., \& Bell, S. (1997). Classification of Mammals above the Species Level. Columbia University Press.

Métais, G., Coster, P. M., Kappelman, J. R., Licht, A., Ocakoğlu, F., Taylor, M. H., \& Beard, K. C. (2018). Eocene metatherians from Anatolia illuminate the assembly of an island fauna during Deep Time. PloS one, 13(11), e0206181. doi: 10.1371/journal.pone.0206181

Nessov, L. A. (1985). [New mammals from the Cretaceous of Kyzylkum]. Vestnik Leningradskogo Universiteta, 7, 8-18. [in Russian]

Novacek, M. J. (1987). Auditory features and affinities of the Eocene bats Icaronycteris and Palaeochiropteryx (Microchiroptera, incertae sedis). American Museum Novitates, 2877, 1-18

O'Connor, J. M., \& Duncan, R. A. (1990). Evolution of the Walvis Ridge-Rio Grande Rise hot spot system: implications for African and South American plate motions over plumes. Journal of Geophysics Research, 95(B11), 17475-17502.

O'Leary, M. A., Bloch, J. I., Flynn, J. J., Gaudin, T. J., Giallombardo, A., Giannini, N. P., Goldberg, S. L., Kraatz, B. P., Luo, Z.-X., Meng, J., Ni, X., Novacek, M. J., Perini, F. A., Randall, Z. S., Rougier, G. W., Sargis, E. J., Silcox, M. T., Simmons, N. B., Spaulding, M., Velazco, P. M., Weksler, M., Wible, J. R., \& Cirranello, A. L. (2013). The placental mammal ancestor and the post-K-Pg radiation of placentals. Science, 339(6120), 662-667. doi: 10.1126/ science. 1229237

Oliveira, É. V., \& Goin, F. J. (2012). Metatérios do início do Paleógeno no Brasil: diversidade e afinidades. In N. C. Cáceres (Ed.), Os Marsupiais do Brasil: Biologia, ecologia e conservação (pp. 275-307). Universidade Federal de Mato Grosso do Sul.

Oliveira, F. B., Molina, E. C., \& Marroig, G. (2009). Paleogeography of the South Atlantic: a route for primates and rodents into the New World? In P. A. Garber, A. Estrada, J. C. Bicca-Marques, E. W. Heymann, \& K. B Strier (Eds.), South American primates (pp. 55-68). Springer.

Pickford, M., \& Mein, P. (2006). Early Middle Miocene mammals from Moroto II, Uganda. Beiträge der Paläontologie, 30, 361-386.

Pickford, M., Senut, B., Morales, J., Mein, P., \& Sánchez, I. M. (2008). Mammalia from the Lutetian of Namibia. Memoir Geological Survey of Namibia, 20(20), 465-514.

Rage, J. C. (2003). Relationships of the Malagasy fauna during the Late Cretaceous: northern or southern routes? Acta Palaeontologica Polonica, 48(4), 661-662.

Rage, J. C., \& Rocek, Z. (2007). A new species of Thaumastosaurus (Amphibia: Anura) from the Eocene of Europe. Journal of Vertebrate Paleontology, 27(2), 329-336. doi: 10.1671/0272-4634(2007)27[329:ANSOTA]2.0.CO;2

Ravel, A., Marivaux, L., Tabuce, R., Ben Haj Ali, M., Essid, E. M., \& Vianey-Liaud, M. (2012). A new large philisid
(Mammalia, Chiroptera, Vespertilionoidea) from the late Early Eocene of Chambi, Tunisia. Palaeontology, 55(5), 1035-1041. doi: 10.1111/j.1475-4983.2012.01160.x

Rose, K. D. (2012). The importance of Messel for interpreting Eocene Holarctic mammalian faunas. Palaeobiodiversity and Palaeoenvironments, 92(4), 631-647. doi: 10.1007/ s12549-012-0090-8

Rosina, V. V., \& Rummel, M. (2012). The bats (Chiroptera, Mammalia) from the Early Miocene of Petersbuch (Bavaria, Southern Germany). Geobios, 45(5), 463-478. doi: 10.1016/j.geobios.2011.10.015

Sánchez-Villagra, M. R., Seiffert, E. R., Martin, T., Simons, E. L., Gunnell, G. F., \& Attia, Y. (2007). Enigmatic new mammals from the late Eocene of Egypt. Paläontologische Zeitschrift, 81(4), 406-415. doi: 10.1007/BF02990252

Seiffert, E. R. (2010a). The oldest and youngest records of afrosoricid placentals from the Fayum Depression of northern Egypt. Acta Palaeontologica Polonica, 55(4), 599-616. doi: 10.4202/app.2010.0023

Seiffert, E. R. (2010b). Paleogene "insectivores". In L. Werdelin, \& W. J. Sanders (Eds.), Cenozoic Mammals of Africa (pp. 253-260). University of California Press.

Simons, E. L., \& Bown, T. M. (1984). A new species of Peratherium (Didelphidae; Polyprotodonta): the first African marsupial. Journal of Mammalogy, 65(4), 539548.

Simmons, N. B., Seiffert, E. R., \& Gunnell, G. F. (2016). A new family of large omnivorous bats (Mammalia, Chiroptera) from the Late Eocene of the Fayum Depression, Egypt, with comments on use of the name "Eochiroptera". American Museum Novitates, 3857, 1-43. doi: 10.1206/3857.1

Smith, T., \& Smith, R. (2013). A land micro-mammal fauna from the Early Eocene marine Egem deposits (NP12, Belgium) and the first occurrence of the peradectid marsupial Armintodelphys outside North America. Geologica Belgica, 16(4), 302-310.

Smith, T., Rana, R. S., Missiaen, P., Rose, K. D., Sahni, A., Singh, H., \& Singh, L. (2007). High bat (Chiroptera) diversity in the Early Eocene of India. Naturwissenschaften, 94(12), 1003-1009. doi: 10.1007/ s00114-007-0280-9

Thomas, O. (1904). On the osteology and systematic position of the rare Malagasy bat Myzopoda aurita. Proceedings of Zoological Society of London, 74(3), 2-6.

Trouessart, E. L. (1879). Catalogue des mammifères vivants et fossiles. Insectivores. Revue et Magasin de Zoologie Pure et Appliquée, 3, 219-285.

Van Couvering, J. A., \& Delson, E. (2020). African Land Mammal Ages. Journal of Vertebrate Paleontology, 40(5), e1803340. doi: 10.1080/02724634.2020.1803340

Van Valen, L. M. (1967). New Paleocene insectivores and insectivore classification. Bulletin of the American Museum of Natural History, 135, 217-284.

Vullo, R., Gheerbrant, E., de Muizon, C., \& Neraudeau, D. (2009). The oldest modern therian mammal from Europe and its bearing on stem marsupial paleobiogeography. Proceedings of the National Academy of Sciences, 106(47), 19910-19915.

Waddell, P. J., Okada, N., \& Hasegawa, M. (1999). Towards resolving the interordinal relationships of placental mammals. Systematic Biology, 48(1), 1-5.

Williamson, T. E., Brusatte, S. L., \& Wilson, G. P. (2014). The origin and early evolution of metatherian mammals: the Cretaceous record. ZooKeys, 465, 1-76. doi: 10.3897/ zookeys.465.8178 